\title{
RESPONSE OF CONSERVATION MEASURES FROM SMALL CULTIVATED WATERSHEDS, CONCERNING RUNOFF AND EROSION, UNDER THE IMPACT OF EXTREME RAINFALL EVENTS
}

\author{
Popa Nelu \\ Research and Development Centre for Soil Erosion Control Perieni \\ Barlad, Romania \\ nelu_c_popa@yahoo.com
}

\begin{abstract}
The study has been made in a representative small watershed with gently to hilly slopes from Tutova Rolling Hills, Romania. The system of conservation measures is represented by stripcroping, bufferstrips, bench terraces, a grassed waterway and a drainage network.

The monitoring of hydrological response of agricultural units has been made in two cross section corresponding to each of the land use type by means of two concrete triangular weirs.

The most important soil losses were caused by three extreme rainfall events from August 29, 2004 (76.3 mm), May 07, 2005 (53.5 mm) and September 05, 2007 (88.5 $\mathrm{mm})$.

At the date of the first rainfall event, generally, the soil was very well protected against erosion by the vegetative cover, excepting parcels that were just ploughed after the mash crop. In that case, it was estimated that the value of soil losses ranged between 20.0 and 24.5 t/ha while for the other crops like corn and soybean, soil losses they were 1.0-1.5 t/ha and 0.5-0.8 t/ha respectively.

Maximum values of runoff were $4.14 \mathrm{~m}^{3} / \mathrm{s}$ for the cultivated land and $2.81 \mathrm{~m}^{3} / \mathrm{s}$ for the grazing land. It was calculated that through cross section corresponding to the cultivated land run about $9100 \mathrm{~m}^{3}$ of water that represent cca. $12 \%$ from the total precipitation.

Damages caused by the rainfall from September 2007 were much more important because at that time about 30\% from the entire surface was just prepared for rape seeding. Maximum value of erosion was $95 \mathrm{t} / \mathrm{ha}$ on a parcel with $16 \%$ slope and $50 \mathrm{~m}$ length along the slope. Net erosion for the entire watershed was estimated to $22 \mathrm{t} / \mathrm{ha}$. Runoff through the main cross section has a maximum of $6.25 \mathrm{~m}^{3} / \mathrm{s}$ and the surface drainage network discharged was about $13000 \mathrm{~m}^{3}$ of water.
\end{abstract}

Keywords: runoff, soil losses, grassed waterway, stripcroping, bench terraces.

\section{$1 \quad$ INTRODUCTION}

Romania has a variety of landscapes resulting from its wide range of major relief forms which are very well proportioned: 36\% Carpathian Mountains and Subcarpathians, $34 \%$ hills and tablelands, and $30 \%$ plains. Within its boundaries live 23.5 millions people.

Hot summers and cold winters, variability in the distribution of rainfall, fluctuating length of growing season typify Romanian continental-temperate climate. There is a crossing of three main climatic influences as follow: Mediterranean (subtropical) 
climate, central European climate (under Atlantic air masses) and east European climate by excessive continental nuance.

Under these natural conditions, erosion processes are numerous and the following forms represent them: sheet erosion, gully erosion and landslides.

In Romania existed and are still maintaining the traditional conservation measures on the agricultural fields. Among them, are mentioned the following: contouring (the practice of tillage and planting on the contour), stripcropping, buffer stripcropping, agroterracing on cropland, wine and fruit plantation terraces, gully control structures, perennial grasses in the crop rotation system and artificial revegetation of the denuded fields by shrubs and trees.

Unfortunately, these methods have not been generalized. Consequently, in some areas were practiced on large scale methods that enabled increasing of erosion as fallow: up-and-down hill plot layout and farming, land clearing for agricultural purposes on hillsides with high risk of erosion. Many indigenous forests were removed by ax and fire, while pastures were overgrazed or the sod turned by plow into cropland.

During the last decades erosion experiments have been developed on small watersheds with predominant agricultural or forestry land use. There have been elaborated methods of runoff and erosion estimation. The concept of an integrated system has been elaborated for rational treatment and use of the eroded soils. There have been elaborated treatment drafts, which take in hypotheses to choose the solutions depending on the climatic zone, soil conditions and relief.

The present trend of scientific research is to find indicators easy to measure and to define the behaviour of the environment in relation to runoff and erosion risks.

Effectiveness of soil conservation measures is proved mainly during the extreme rainfall events when the amount of soil losses may be very important.

\section{MATERIALS AND METHODS}

\section{$2.1 \quad$ Study site}

The study area is located in in a representative small watershed named Gheltag (Popa N. et. al. 2005) with gently to hilly slopes from Tutova Rolling Hills, Romania where the soil is represented by grey wood soil, highly eroded. The terrain that has almost 100 ha arable land and 18 ha pasture was fit out by different conservation measures in the period of 19775-1977 when it belonged to the Stat.

After Romanian revolution from 1989, according to the new laws on land property, the entire surface of Gheltag basin was realloted to 83 old landowners, on the original locations that means that the plots consisted in long and narrow strips, disposed up-and-down the hill. This situation made impossible applying of the contour tillage system and leads to abandon of the majority of conservation practices. Since 2002 the terrain was leased by Perieni Research Centre and was completely rehabilitated. The following soil conservation measures were used: intercropping, contour planting, strip cropping, bench terraces, a grassed waterway and a drainage network (figure 1).

It has to be mentioned that some landowners, did not agree with the project and they continued to work the land on their own. 
Two stations provided meteorological data. One of them is located $5 \mathrm{~km} \mathrm{S-E}$, in Barlad town and it registered data since 1941. The other one is an automatical station and is positioned in the neighbourhood of the site, on the territory of Perieni Research Centre.
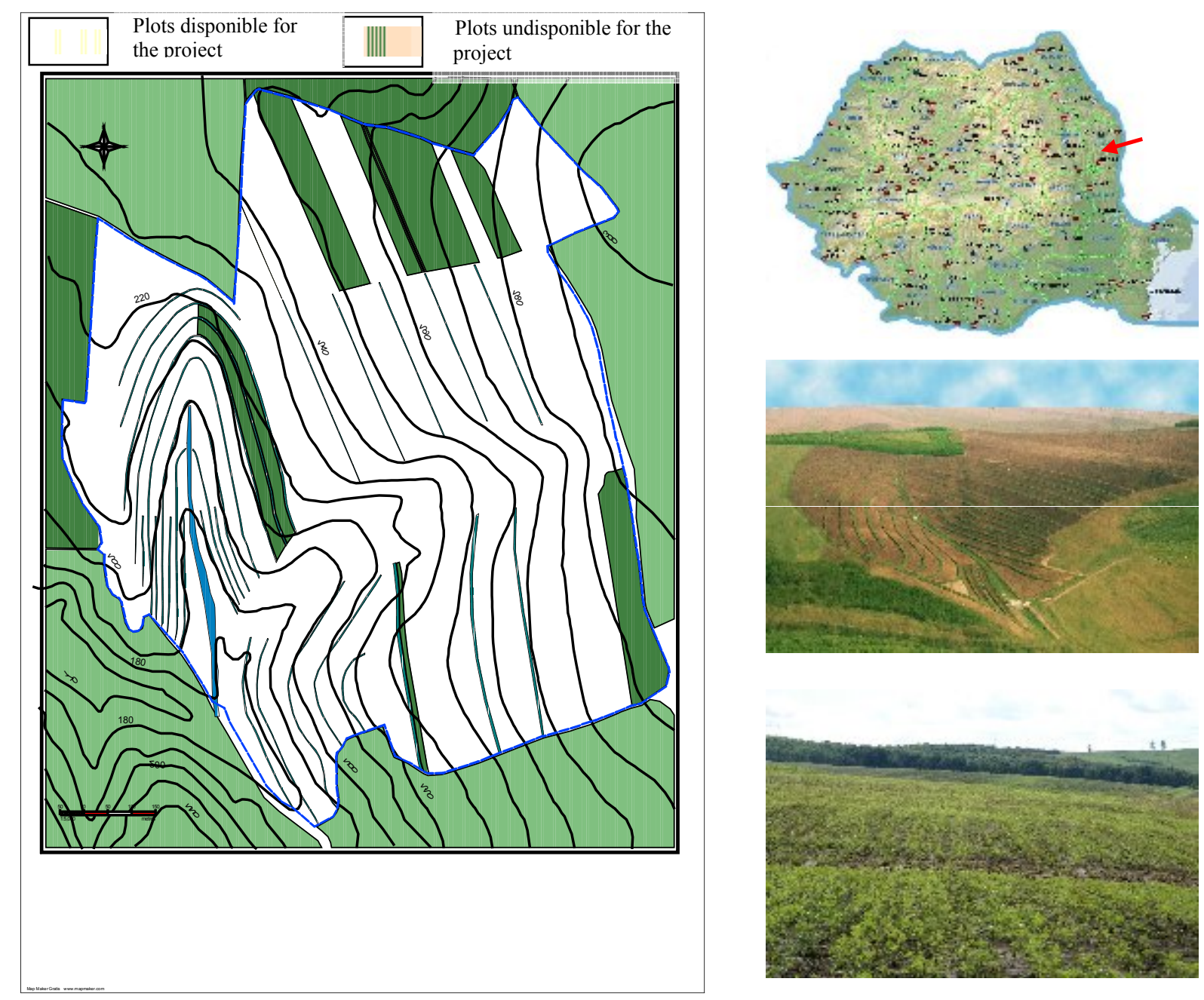

Figure 1 Inventory of agricultural plots from Gheltag watershed, Tutova Rolling Hills, Romania

Historical registrations indicated that yearly average of precipitation and temperature at Barlad station are $494 \mathrm{~mm}$ and $9.8^{\circ} \mathrm{C}$ respectively. A maximum monthly average of precipitation is placed in June with $76.8 \mathrm{~mm}$ while the minimum is $24.1 \mathrm{~mm}$ in March. The critical season of erosion is between May and August but in the last decade data showed that these limits are about to change and they trend to enlarge until the middle of September.

The last extreme rainfall events that were associated with the highest values of runoff and erosion were registered in August 29, 2004 (76.3 mm), May 07, 2005 (53.5 mm) and September 05, 2007 (88.5 mm).

\subsection{Experimental methods}

The monitoring of hydrological response of agricultural units was performed in two cross section corresponding to each of the land use type (cultivated land and 
pasture) by means of two short-crested triangular weirs. This weir type was developed by Natural Resources Conservation Service - US Department of Agriculture (Brakensiek et al., 1979) and its characteristics are presented in figure 2 and equation [1]

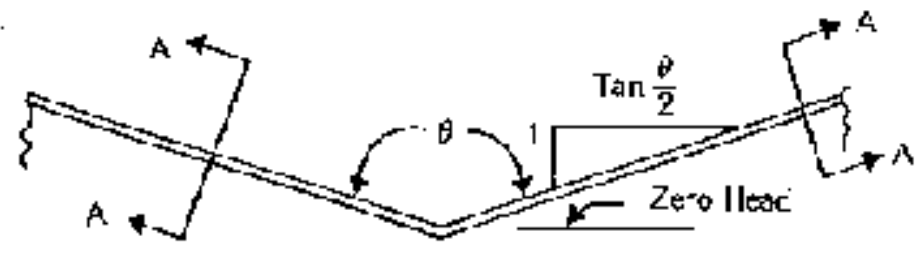

Elewetion

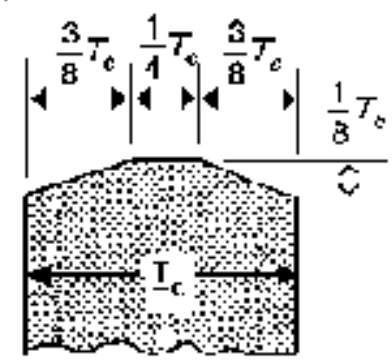

Secti:an A-A

Figure 2 Short - crested triangular weir

The discharge equation for the short - crested triangular weir is the following:

$Q=\left(C_{0}+C_{1} \log _{10} \frac{h}{T_{c}}\right) \sqrt{g} \tan \frac{\theta}{2}\left(h+\alpha \frac{v^{2}}{2 g}\right)^{2.5}$

$\theta=150^{\circ}$

$\propto=1.33$

$v=$ average velocity in cross section $3 \mathrm{~m}$ upstream from center of crest;

$\mathrm{h}=$ head $3 \mathrm{~m}$ upstream from center of crest;

$\mathrm{T}_{\mathrm{c}}=$ crest thickness $(0.4 \mathrm{~m})$;

$\mathrm{C}_{\mathrm{o}}, \mathrm{C}_{1}=$ correction factors.

Assessing soil losses on every parcel was performed mainly by conventional methods (topographical measurements) after every most important rainfall events. However, on some plots with steep slopes, the Cs-137 technique was adopted to evaluate the effectiveness of conservation measures on medium term. Thus, 7 sampling points disposed on a representative transect were selected to characterize the effectiveness of the narrow terraces in diminishing of soil erosion processes on hilly slopes. In soil losses calculating, Cs-137 inventory was determined and some conversional models like Mass Balance Models developed by Walling D.E. (2007) were used. The main advantage of this technique is the possibility to analyze erosion and to have a diagnostic of the soil status even for a single visit in the field.

\section{$3 \quad$ RESULTS AND DISCUTIONS}

On August 29, 2004, when the rainfall reached $76.3 \mathrm{~mm}$ in 90 minutes, the stage of the crops was the following:

- 24 ha from the total of 100 ha were just ploughed after the mash crop; 
- 52 ha were covered by winter wheat stubble;

- the height of corn plants (12 ha) had the maximum value;

- 12 ha were occupied by soybean.

On areas with gently to rolling slopes, the most important soil losses were caused by the pattern of relief formed many years ago when the tillage up-and-down the hill was usually executed. Even today, where contour cropping and strip cropping systems are applied, the former microchannels still exist (figure 1).

Measured data were compared to those obtained from the parcels situated in the neighborhood which, approximately are in the same conditions of soil and relief but they are disposed up-and-down the hill.

On the surface covered by corn it was found, for example, that values of erosion ranged between 6.5 and 14 t/ha while in Gheltag basin soil losses were 1.0-1.5 t/ha for corn and 0.5-0.8 t/ha for soybean.

The worst situation was met on the plots just ploughed after the mash crop where it was estimated that the values of soil losses varied between 20.0 and $24.5 \mathrm{t} / \mathrm{ha}$. On the similar conditions, the parcels disposed up-and-down were eroded by $35-45 \mathrm{t} / \mathrm{ha}$. On the plots with winter wheat stubble, the remainders of vegetation constituted a very good protection of soil against erosion and soil losses were insignificantly.

The grassed waterway worked good enough, thus excess of water was rapidly evacuated without trigging rill erosion. Maximum values of runoff registered on short - crested triangular weirs were $4.14 \mathrm{~m}^{3} / \mathrm{s}$ for the cultivated land and $2.81 \mathrm{~m}^{3} / \mathrm{s}$ for the grazing land. It was calculated that through cross section corresponding to the cultivated land run about $9100 \mathrm{~m}^{3}$ of water that represent cca. $12 \%$ from the total precipitation.

At the time of rainfall from May 07, 2005 (53.5 mm in 80 minutes) 48 from 100 ha were covered by winter wheat and the rest of 52 ha were just seeded by pea ( $11 \mathrm{ha})$, soybean (19 ha), mustard (16 ha) and corn (6 ha). Therefore, not merely the terrain was uncovered by vegetation but also the surface of soil was finely hoed, creating ideal conditions for surface erosion. It was estimated that erosion varied locally between 15 and $35 \mathrm{t} / \mathrm{ha}$, depending on the hill slope. For the whole basin the average of erosion was about 10-12 t/ha, having in sight the influence of stripcroping system where the parcels with bare soil alternated with those covered by winter wheat.

In the same manner like in previous described case, the most important soil losses were registered on the bare soil, situation that also owed to the pattern of soil surface characterized by small microchannels formed during the former agricultural system.

Measurements on above described weirs indicated that maximum values of runoff were 4.63 and $3.17 \mathrm{~m}^{3} / \mathrm{s}$. They showed that even the level of precipitation was lower than the first analyzed situation, conditions concerning soil status were much more favorable for developing runoff and erosion.

The last analyzed is the rainfall from September 05, 2007 which reached $88.5 \mathrm{~mm}$ in more than 200 minutes. Practically, 4 rainfall events in a single day succeeded with short intervals between them.

Damages caused by these rainfalls were significantly higher than the previous described rain events because, at that time, about $30 \%$ from the entire surface was just prepared for rape seeding. Maximum value of erosion was $95 \mathrm{t} / \mathrm{ha}$ on a parcel with $16 \%$ slope and $50 \mathrm{~m}$ lengths along the slope. Net erosion for the entire watershed was estimated to $22 \mathrm{t} / \mathrm{ha}$. Runoff through the main cross sections have maximum values of 6.25 and $4.05 \mathrm{~m}^{3} / \mathrm{s}$ and the surface drainage network discharged about $13000 \mathrm{~m}^{3}$ of water. They were the highest values registered in Gheltag basin since it was monitored. 
On the bare soil from small private plots disposed up-and-down, estimated soil losses varied between 47 and 110 t/ha depending on relief parameters. On the other hand, an insignificant percentage of private lands were ploughed and hoed at that date for the reason that majority of small landowners do not plant rape which is usually seeded in September but winter wheat that is seeded one month later. Thus, more than $95 \%$ of terrains were covered by vegetation and a low level of erosion processes were noticed.

Finally, to have an image about behavior of conservation practices on the steep slopes, some measurements using Cs-137 technique for a representative part of the basin were performed. Methodology took into account the effects of all factors that influenced erosion processes till the end of 2007.

On narrow terraces, redistribution of soil was mainly assigned to tillage erosion. Thus, measurements in the upper part of bench terraces, from which values of ${ }^{137} \mathrm{Cs}$ inventory were below the reference, indicated that significant erosion in the last decades occurred. Year by year, soil was translocated to the lower edge of terraces, process reflected by high values of ${ }^{137} \mathrm{Cs}$ activity in the lowest sampling points of terraces.

Values of soil losses calculated by Mass Balance 3 Model (Walling D.E. et al. -2007) ranged between 8.3 and $18.6 \mathrm{t} / \mathrm{ha} / \mathrm{y}$ while values of deposition were situated between 22.1 and $57.8 \mathrm{t} / \mathrm{ha} / \mathrm{y}$. However, net erosion for the entire transect was $1.8 \mathrm{t} / \mathrm{ha} / \mathrm{y}$ that is an acceptable value if compared to soil loss tolerance, which is $2-6 \mathrm{t} / \mathrm{ha} / \mathrm{y}$ in Gheltag basin.

The above-presented situations are representatives for the natural conditions of the investigated site and showed that arable land has to be much more protected by vegetation, especially in the spring and in the autumn, when the crops are seeded. That means that alternating crops, contouring system, stripcrops system, and generally, all conservation practices have to be more carefully managed having in sight that the rainfalls are already much more aggressive due to changing climate.

\section{CONCLUSIONS}

- Much as professionally realized, soil conservation measures can be affected in different degrees by erosion if the rainfalls go beyond the limits took into account in designing activity. However, on places where conservation practices were applied, soil losses caused by the extreme rainfall events were about three times more reduced than those from the parcels disposed up-anddown the hill.

- Alternating crops, contouring system, stripcrops system, and generally, all conservation practices from agricultural land play more and more important roll in controlling runoff and erosion because rainfalls are already much more aggressive due to changing climate.

\section{References}

Brakensiek, D.L., H.B. Osborn, and W.R. Rawls (1979), Field Manual for Research in Agricultural Hydrology, Agricultural Handbook 224, U.S. Department of Agriculture, U.S. Government Printing Office, Washington, DC.

Popa N., E. Filiche, Gh. Purnavel (2002) Stages of soil degradation by erosion, Scientific papers", Agronomy Series of University of Agricultural Sciences and Veterinary Medicine lasi, Romania. 
Popa N., D. Nistor, V. Năstasă, GH. Purnavel, E. Filiche, G. Petrovici (2005) Gheltag basin from Tutova Rolling Hills, Romania din Colinele Tutovei, model of land management for the private agricultural land. „Scientific papers” Vol. 48, Agronomy Series of University of Agricultural Sciences and Veterinary Medicine lasi, Romania.

Walling D.E., Y. Zhang, Q. HE, Models for Converting Radionuclide $\left({ }^{137} \mathrm{Cs}\right.$, Excess ${ }^{210} \mathrm{~Pb}$, and $\left.{ }^{7} \mathrm{Be}\right)$ Measurements to Estimates of Soil Erosion and Deposition Rates (Including Software for Model Implementation-2007) CD 